\title{
Sistem Pendukung Keputusan Dengan Metode AHP Untuk Menentukan Lokasi Tempat Pembuangan Akhir Sampah di Asahan
}

\author{
Pahrunnisa Panjaitan ${ }^{1 *}$, Zulfi Azhar ${ }^{2}$ \\ 1,2 Program Studi Sistem Informasi, STMIK Royal Kisaran, Indonesia \\ ${ }^{2}$ zulfi_azhar@yahoo.co.id
}

\begin{tabular}{ll}
\hline open & Abstrak \\
Keberadan Tempat Pembuangan Akhir Sampah (TPA) saat ini seringkali \\
menjadi permasalahan ditinjau dari kesehatan lingkungan, kehidupan sosial,
\end{tabular}

\section{PENDAHULUAN}

Pada era globalisasi saat ini teknologi komputer memegang peranan yang sangat penting dalam membantu proses aktivitas kerja di instansi maupun di perkantoran pemerintah maupun swasta. Penggunaan perangkat komputer sebagai perangkat pendukung menajemen dan pengolahan data adalah sangat tepat dan sangat diperlukan dalam kegiatan manajemen atau perkantoran.

Keberadaan TPA saat ini seringkali menjadi permasalahan ditinjau dari kesehatan lingkungan, kehidupan sosial, keadaan budaya dan pertumbuhan ekonomi. Komponen tersebut kerap kali menjadi hambatan dalam pengadaan sarana TPA dan seringkali menjadi suatu permasalahan yang besar dalam suatu daerah terlebih pada daerah perkotaan. Lahan untuk TPA dirasakan sudah tidak dialokasikan lagi dalam rencana tata ruang yang tepat. Suatu wilayah yang direncanakan untuk menjadi lokasi TPA seharusnya mempunyai karakteristikkarakteristik geografis tersendiri, dimana suatu lahan memiliki kelebihan dan kekurangannya masing-masing misalnya daerah tertentu memiliki kondisi air tanah yang bagus namun dekat dengan pemukiman penduduk atau daerah lain memiliki kondisi air tanah yang kurang bagus namun jauh dari pemukiman penduduk.

Di daerah Asahan khususnya kota Kisaran mempunyai permasalahan mengenai banyaknya sampah yang harus dikelola dengan baik sementara tempat pembuangan sampah yang ada tidak mampu sebagai tempat pembuangan akhir sampah. Hal tersebut sering muncul dalam penanganan sampah kota, yang berhubungan dengan biaya operasional yang tinggi, semakin sulitnya ruang yang layak untuk pembuangan dan terbatasnya lahan yang layak untuk lokasi pembuangan sampah. Sementara Tempat Pembuangan Akhir (TPA) sampah di Asahan merupakan salah satu komponen akhir dalam pengelolaan persampahan masyarakat Asahan.

Terdapat banyak informasi yang dibutuhkan untuk memilih wilayah yang ideal untuk Lokasi Tempat Pembuangan Akhir Sampah. Pemanfaatan Sistem Pendukung Keputusan dapat digunakan untuk membantu manusia dalam mengambil keputusan dengan cepat, tepat dan konsisten. Sistem Pendukung Keputusan sangat tepat jika diterapkan pada permasalahan yang cukup kompleks seperti permasalahan ini dalam menentukan lokasi Tempat Pembuangan Akhir sampah.

\section{STUDI LITERATUR}

Sampah merupakan masalah yang serius di dalam masyarakat jika tidak ditangani dengan benar, apalagi masyarakat yang tinggal di perkotaan. Masalah yang sering muncul dalam penanganan sampah kota adalah 
masalah biaya operasional yang tinggi, semakin sulitnya ruang yang pantas untuk pembuangan, dan terbatasnya lahan yang layak untuk lokasi pembuangan sampah yang ada di sekitar perkotaan menyebabkan dampak negatif terhadap lingkungan. Untuk mengatasi masalah tersebut diperlukanlah suatu sistem yang dapat membantu memberikan solusi dalam pemilihan tempat akhir pembuangan sampah yang efektif(Afrisawati 2018).

Sampah adalah suatu bahan yang terbuang atau dibuang dari sumber hasil aktifitas manusia maupun alam yang belum memiliki nilai ekonomis. Sampah berasal dari rumah tangga, pertanian, perkantoran, perusahaan, rumah sakit, pasar, dan lain-lain. Permasalahan sampah menjadi keluhan seluruh masyarakat desa maupun kota, oleh karena itu perlu ditangani agar tidak menimbulkan masalah yang berkelanjutan(Sugiyani 2016).

Penentuan TPA sampah harus mengikuti persyaratan dan ketentuan-ketentuan yang telah ditetapkan pemerintah. Diharapkan dengan mengikuti kriteria-kriteria penentuan lokasi TPA hendaknya dapat meminimalisir dampak kerusakan dan pencemaran lingkungan di sekitar lokasi TPA karena semuanya ditetapkan memperhatikan banyak aspek lingkungan, kesehatan, dan kebersihan, seperti kondisi geologis, mata air, lokasi pemukiman, dan lokasi lahan yang masih produktif(Fachrial, Arifin, and Khairina 2017).

Dalam membantu pengambilan keputusan dari sejumlah pilihan diperlukan sistem, memberikan solusi akhir pilihan yang terbaik. Sistem pendukung keputusan bagian dari Artifical Intelligence yang digunakan untuk memberikan jawaban dari proses perhitungan dari sejumlah pilihan dengan tujuan tertentu. Manfaat SPK memperluas, membantu, menghasilkan solusi stimulan bagi pengambil keputusan dalam memahami persoalannya dengan menyajikan berbagai alternatif pemecahan. Pengambilan keputusan dalam pembuat keputusan manajemen dari masalah semi terstruktur(Na'am 2017). Penggunaan AHP memerlukan sejumlah kriteria yang dicari berdasarkan tujuannya. Sejumlah alternatif adalah pilhan yang akan ditentukan melalui proses perhitungan(Andrade et al. 2015)(Septiani and Siahaan 2017)(Umar, Fadlil, and Yuminah 2018). Sistem pada AHP lebih sederhana dan efektif dalam penggunaan pengambilan hasil yang terbaik. Pengetahuan yang terinci dalam menyusun realitas yang kompleks kedalam bagian elemen pokok, kemudian dibagi kedalam bagian-bagiannya lagi, secara hierarki(Azhar, Jama, and Effendi 2021)(Komsiyah 2014)(Wahyu, Safriadi, and Pratiwi 2017)(Azhar, Effendi, and Muskhir 2021)(Frieyadie and Ramadhan 2018)(Mardiyati, Juliana, and Driyani 2016)(Mary 2014)(Hasugian et al. 2018)

Dalam metode ini diperlukan beberapa kriteria dan beberapa alternatif sebagai pilihan yang ditentukan melalui proses perhitungan(Andika n.d.). Cara ini lebih mudah dan efektif untuk menghasilkan yang terbaik. menjadikan bagian-bagian hierarki dan bertahap(model pembelajaran)

\section{Metode Analytical Hierarchy Process (AHP)}

Tahapan dalam AHP yaitu :

a. Pendefinisian permasalahan yang terjadi dengan memberikan pembagian secara hierarki secara tersusun.

b. Membuat penentuan prioritas menggunakan pasangan matriks.

c. Sintesis dengan memperbandingkan secara matriks dalam mendapatkan hasil nilai yang prioritas.

d. Hasil ukuran konsistensi

Hasil ukuran konsistensi berdasarkan rumus yang yang telah ditentukan yang dibuatkan dalam tabel.

e. Pengukuran hasil nilai Consistency Index, yaitu :

$$
\mathrm{CI}=\frac{[\lambda \max -n]}{\mathrm{n}-1}
$$

$\mathrm{n}=$ banyak jumlah elemen

$\lambda$ maks $=$ angka eigen maksimum dari matriks perbandingan yang berpasangan

f. Mendapatkan nilai Rasio Konsistensi

yaitu :

$$
\mathrm{CR}=\frac{C I}{R I}
$$

yaitu

$\mathrm{CR}=$ Rasio Consistency,

$\mathrm{CI}=$ Indeks Consistency,

$\mathrm{RI}=$ Indeks secara Random

g. Hasil nilai konsistensi secara hirarki.

Penilain konsistensi secara hirarki jika nilai perhitungan itu sebagai hasil bernilai benar.

$\mathrm{CR}<0,1$ 


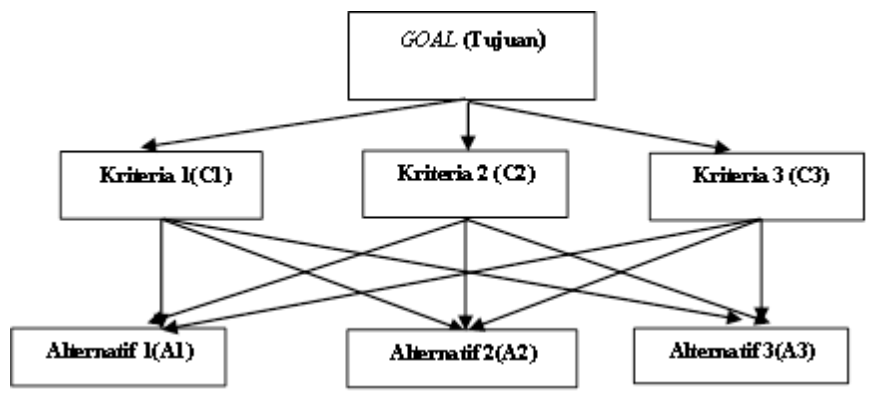

Gambar 1. Bagan Hierarki Pada Metode AHP

\section{METODE}

Metode yang digunakan dengan beberapa tahap yaitu:

a. Tahap 1 Mengumpulkan Dokumen Data

Pengumpulan data dilakukan di lapangan dengan memilih sejumlah kriteria dan alternatif menggunakan pengisian formulir oleh 30 orang petugas sampah yang selalu menangani sampah di Asahan. Mereka diminta untuk membandingkan kriteria yang dibutuhkan dengan data tersebut yang akan diolah untuk dianalisis.

b. Tahap 2 Menganalisa Data

Menganalisa data dengan sejumlah kriteria dan alternatif yang dipilih sesuai tujuan yang direncanakan.

c. Tahap 3 Menggunakan proses uji pada Sistem.

Menggunakan matriks excel, untuk pengujian perhitungan pada sistem.

a. Pemilihan Kriteria

\section{HASIL}

Pemilihan kriterianya adalah: Pemukiman(C1), Kemiringan(C2), Sumber Air (C3) dan Air Tanah(C4). Penilaian indeks konsistensi pada kriteria perhitungan menjadi konsistensi jika angka rasio konsistensi hierarkis $(\mathrm{CR})<0,1$. Nilai maksimum adalah jumlah perkalian dalam kolom matriks synthes sebanding pada kriteria di tabel 1 dan tabel 2.

Tabel 1. Perhitungan Untuk Kriteria

\begin{tabular}{ccccc}
\hline Kriteria $(\mathrm{Crt})$ & Pemukiman(C1) & Kemiringan(C2) & Sumber Air(C3) & Air Tanah(C4) \\
\hline Pemukiman(C1) & 1 & 2 & 3 & 4 \\
Kemiringan(C2) & 0,5 & 1 & 2 & 3 \\
Sumber Air(C3) & 0,333 & 0,5 & 1 & 2 \\
Air Tanah(C4) & 0,25 & 0,333 & 0,5 & 1 \\
Jumlah & 2,0833 & 3,833 & 6,5 & 10 \\
\hline
\end{tabular}


Tabel 2. Normalisasi Pada Kriteria dan Rangking

\begin{tabular}{cccccccc}
\hline $\begin{array}{c}\text { Kriteria } \\
(\mathrm{Crt})\end{array}$ & $\mathrm{C} 1$ & $\mathrm{C} 2$ & $\mathrm{C} 3$ & $\mathrm{C} 4$ & Jumlah & Prioritas & Rangking \\
\hline C1 & 0,480 & 0,522 & 0,462 & 0,400 & 0,100 & 0,466 & 1 \\
C2 & 0,240 & 0,261 & 0,308 & 0,300 & 1,109 & 0,277 & 2 \\
C7 & 0,160 & 0,130 & 0,154 & 0,200 & 0,644 & 0,161 & 3 \\
C4 & 0,120 & 0,087 & 0,077 & 0,100 & 0,384 & 0,096 & 4 \\
Jumlah & 1 & 1 & 1 & 1 & 4 & & \\
\hline
\end{tabular}

Tabel 3. Random Indeks

\begin{tabular}{ccccccccccccccc}
\hline $\mathrm{n}$ & 1,2 & 3 & 4 & 5 & 6 & 7 & 8 & 9 & 10 & 11 & 12 & 13 & 14 & 15 \\
\hline $\mathrm{RI}$ & 0 & 0,58 & 0,90 & 1,12 & 1,24 & 1,32 & 1,41 & 1,45 & 1,49 & 1,51 & 1,48 & 1,56 & 1,57 & 1,59 \\
\hline
\end{tabular}

$\lambda$ maks $=(2,0833 * 0,466)+(3,833 * 0,277)+(6,5 * 0,161)+(10 * 0,096)$

$\lambda$ maks $=4,0395$

$C I=\frac{4,0395}{(4-1)} \quad \mathrm{CI}=0,013161464$

Penentuan angka $\mathrm{RI}=0,9$ dari tabel dengan nilai $\mathrm{n}=4$.

$C R=\frac{0,013161464}{0,9}=0,014623849$

Hasil CR = 0,014623849 memenuhi syarat, $\mathrm{CR}<0,1$ dinyatakan konsisten/benar.

b. Pemilihan Alternatif

Kriteria yang terpilih yaitu Permukiman(C1). Pemilihan Alternatif (A) dalam menentukan lokasi tempat pembuangan akhir sampah adalah: Silo Laut(A1), Kisaran Timur(A2) dan Pulo Bandring(A3).

Tabel 4. Perhitungan Pada Alternatif

\begin{tabular}{cccc}
\hline Alternatif(A) & Silo Laut(A1) & Kisaran Timur(A2) & Pulo Bandring(A3) \\
\hline Silo Laut(A1) & 1 & 0,5 & 0,2 \\
Kisaran Timur(A2) & 5 & 3 & 1 \\
Pulo Bandring(A3) & 0,333 & 0,333 & 0,2 \\
Jumlah & 8,333 & 4,833 & 1,733 \\
\hline
\end{tabular}

Tabel 5. Normalisasi Pada Alternatif dan Rangking

\begin{tabular}{ccccccc}
\hline Alternatif $(\mathrm{A})$ & $(\mathrm{A} 1)$ & $(\mathrm{A} 2)$ & $(\mathrm{A} 3)$ & Jumlah & Prioritas & Rangking \\
\hline (A1) & 0,545 & 0,429 & 0,600 & 1,574 & 0,525 & 1 \\
(A2) & 0,182 & 0,143 & 0,100 & 0,425 & 0,142 & 3 \\
(A3) & 0,273 & 0,429 & 0,300 & 1,001 & 0,334 & 2 \\
Jumlah & 1 & 1 & 1 & 3 & & \\
\hline
\end{tabular}

Penilaian indeks konsistensi pada alternatif adalah :

$\lambda$ maks $=(8,333 * 0,525)+(4,833 * 0,142)+(1,733 * 0,334)$

$\lambda$ maks $=3,065367965$

$C I=\frac{3,065367965-3}{(3-1)} \quad \mathrm{CI}=0,032683983$

Penentuan angka $\mathrm{RI}=0,58$ dari tabel dengan nilai $\mathrm{n}=3$.

$C R=\frac{0,032683983}{0,58} \quad \mathrm{CR}=0,056351694$, bersifat konsisten dimana $\mathrm{CR}<0,1$.

Pada penilaian akhir dari hasil pengujian maka pemilihan tempat lokasi pembuangan akhir sampah yang prioritas berdasarkan kriteria Permukiman(C1) adalah Silo Laut(A1) yang terpilih berdasarkan kriteria permukiman.

\section{PEMBAHASAN}

Penggunaan metode Analytical Hierarchy Process(AHP) dalam pemilihan tempat lokasi pembuangan akhir sampah dapat menghasilkan kriteria dan alternatif yang prioritas. Sistem ini dapat membuat suatu keputusan dengan menentukan beberapa kriteria dan alternatif dalam memberikan solusi penyelesaian dalam menentukan pilihan dari beberapa kriteria dan alternatif yang ditetapkan. 


\section{KESIMPULAN}

Kesimpulan akhir ini dari penelitian ini bahwa penggunaan metode AHP dapat menghasilkan pemilihan tempat lokasi pembuangan akhir sampah dengan beberapa kriteria pemilihan yang berpengaruh dan juga alternatif-alternatif terpilih. Nilai perangkingan yang diperoleh dari alternatif dengan nilai berurutan adalah Silo Laut(A1), Pulo Bandring(A3) dan Kisaran Timur(A2).

\section{REFERENSI}

Afrisawati. 2018. "Sistem Pendudkung Keputusan Pemilihan Lokasi Tempat Pembuangan Akhir Sampah Dengan Metode Anp ( Studi Kasus: Dinas Tata Kota Kabupaten Asahan ).” Seminar Nasional Royal (SENAR) 2018 9986(September): $121-124$.

Andika, Rheza. n.d. "Analytic Hierarchy Process (AHP) Dan Perhitungan Contoh Kasus AHP."

Andrade, André, João De Deus, Rodrigues Gois, and Paulo Roberto. 2015. "Proposal for Using AHP Method to Evaluate the Quality of Services Provided by Outsourced Companies." Procedia - Procedia Computer Science 55(Itqm):715-24.

Azhar, Zulfi, Hansi Effendi, and Mukhlidi Muskhir. 2021. "Decision Support System Analytical Hierarchy Process in Learning Method Selection Decision Support System Analytical Hierarchy Process in Learning Method Selection.”

Azhar, Zulfi, Jalius Jama, and Hansi Effendi. 2021. "The Analytical Hierarchy Process of Decision Support Systems in Choosing Learning Models.” 12(10):2278-85.

Fachrial, Aldy;, Zainal; Arifin, and Dyna Marisa; Khairina. 2017. "Sistem Pendukung Keputusan Penentuan Lokasi Pembuangan Akhir Sampah Kota Samarinda Metode Simple Additive Weighting Berbasis Dekstop." Prosiding Seminar Ilmu Komputer Dan Teknologi Informasi 2(1):142-45.

Frieyadie, Frieyadie, and Surya Mahendra Ramadhan. 2018. "Penerapan Metode AHP Untuk Membantu Siswa Memilih Jurusan Yang Tepat Di SMK.” Jurnal RESTI (Rekayasa Sistem Dan Teknologi Informasi) 2(3):662-67.

Hasugian, Abdul Halim, Hendra Cipta, Prodi Ilmu Komputer, and Prodi Matematika. 2018. "Analisa Dan Perancangan Sistem Pendukung Keputusan Pemilihan Pasangan Hidup Menurut Budaya Karo Dengan Menggunakan Metode Analitycal Hierarchy Process ( AHP) Abstrak." 6341(April):14-30.

Komsiyah, Siti. 2014. "Aplikasi Analytical Hierarchy Process (AHP) Pada Pemilihan Software Manajemen Proyek." ComTech: Computer, Mathematics and Engineering Applications 5(2):870.

MARDIYATI, SRI, JULIANA, and DEWI DRIYANI. 2016. "Sistem Penunjang Keputusan Pemilihan Perumahan Dengan Metode AHP." Faktor Exacta 8(2):63-71.

Mary, Thomson. 2014. "Sistem Pendukung Keputusan Menggunakan Metode Analytic Hierarchy Process ( AHP ) Pemilihan Metode Pembelajaran Untuk Mata Kuliah Praktikum Yang Berbasiskan Bahasa Pemrograman Komputer Jurnal Edik Informatika." 1:23-29.

Na'am, Jufriadif. 2017. "Sebuah Tinjauan Penggunaan Metode Analythic Hierarchy Process (AHP) Dalam Sistem Penunjang Keputusan (SPK) Pada Jurnal Berbahasa Indonesia." Jurnal Mediasisfo 11(1978-8126):888-95.

Septiani, Dian, and Fernando B. Siahaan. 2017. "KARYAWAN BERPRESTASI DENGAN METODE ANALITICAL HIERARCHY PROCESS ( AHP ) PADA PT . ICHIYA INDONESIA.” III(1):1-8.

Sugiyani, Yani. 2016. "Sistem Pengambilan Keputusan Penentuan Lokasi Tempat Pembuangan Akhir (Tpa) Sampah Menggunakan Metode Simple Addictive Weighting (Saw).” Jurnal Sistem Informasi 3:1-7.

Umar, Rusydi, Abdul Fadlil, and Yuminah Yuminah. 2018. "Sistem Pendukung Keputusan Dengan Metode AHP Untuk Penilaian Kompetensi Soft Skill Karyawan.” Khazanah Informatika: Jurnal Ilmu Komputer Dan Informatika.

Wahyu, Abang M. Zaid, Novi Safriadi, and Helen Sasty Pratiwi. 2017. "Sistem Pendukung Keputusan Pemilihan Mata Kuliah Pilihan Menggunakan Metode Analytic Hierarchy Process ( Studi Kasus : Jurusan Teknik Elektro Fakultas Teknik Universitas Tanjungpur A ).” Jurnal Sistem Dan Teknologi Informasi (JUSTIN) 5(2):160-63. 